This is the author's version of a work that was published in the following source:

Ensslen, A.; Jochem, P.; Fichtner, W. (2013).

Experiences of EV users in the French-German context

27th World Electric Vehicle Symposium and Exhibition (EVS), International Battery, Hybrid and Fuel Cell Electric Vehicle Symposium, Barcelona, Spain, 17-20 November 2013. Vol. 1, 332-344, IEEE, Piscataway (NJ).

DOI: $\underline{\text { 10.1109/EVS.2013.6914749 }}$

Please note: Copyright is owned by the author(s) and / or the publisher. The commercial use of this copy is not allowed. 


\title{
Experiences of EV Users in the French-German Context
}

\author{
Axel Ensslen ${ }^{1 *}$, Patrick Jochem ${ }^{1}$, Wolf Fichtner ${ }^{1}$ \\ ${ }^{1}$ Chair of Energy Economics, French-German Institute for Environmental Research (DFIU) at the Karlsruhe Institute \\ of Technology, Kaiserstr. 12, Karlsruhe, 76131, Germany \\ ${ }^{*}$ Corresponding author
}

\begin{abstract}
Within the framework of the accompanying scientific research of a fleet test with more than 100 Electric Vehicles (EV, predominantly battery EV) in the French-German border region a user acceptance study is accomplished focusing on transnational trips. Most of the EV are fleet vehicles in companies or public authorities and are used by several persons which increases the potential for the size of the user sample significantly. The acceptance analysis, as part of the fleet test's evaluation concept, consists amongst others of repeatedly questioning the users and fleet managers (i.e. the persons in charge of the $\mathrm{EV}$ in the companies who have partly been involved in the decision making process to acquire the EV) via online surveys with different focuses: expectations, first experiences and EV users' long-term adoption intentions of EV. Even though the potential for EV adoption for respondents living in municipalities with less than 20,000 citizens has been assumed to be high (higher probability of having parking possibilities with power sockets, higher annual car mileage, higher probability of having two or three cars in the household), experiences of EV users within our analysed fleet test indicate, that urban dwellers' (respondents living in municipalities with more than 20,000 citizens) degree of satisfaction with EVs' characteristics absence of local emissions, range and life expectancy of the battery is higher. Furthermore, French respondents' show a higher degree of satisfaction with EVs' maximum speed and $\mathrm{CO}_{2}$ emission characteristics.
\end{abstract}

Keywords: EV (electric vehicle), infrastructure, standardization, fleet, marketing

\section{Introduction}

\subsection{Cross-border Mobility for EVs (CROME)}

Due to different standards concerning hardware and software components - especially concerning components of the charging infrastructure, crossborder mobility with Electric Vehicles (EV) is currently only possible with major restrictions. Achtnicht et al. [1] show that the availability of fuel infrastructure is crucial to the diffusion process of alternative fuel vehicles. The idea of the CROME project is to build up charging infrastructure in order to facilitate cross-border mobility with EV between France and Germany and to give recommendations to the European standardization process on EV charging infrastructure components.

CROME has been initiated by the French ministries MEFI (Ministry of Economy, Finance and Industry) and MSDTH (Ministery of Ecology, Sustainable Development, Transport and Housing) and the German ministries BMWi (Federal Ministry of Economics and Technology) and BMVBS (Federal Ministry of Transport, Building and Urban Development). With the 
support of the CROME partners Bosch, Daimler, EDF, EnBW, Porsche, PSA, Renault, Siemens and Schneider Electric an EV fleet test has been set up by installing hardware and software components for interoperable charging infrastructure. Electric fleet cars have been allocated in the border region (Alsace, Lorraine and Baden-Württemberg). The idea of CROME is to permit seamless, reliable and user-friendly electric mobility between France and Germany by building up a European e-mobility platform open for OEMs (Original Equipment Manufacturers), energy utilities, local authorities and others. CROME analyses electric mobility usage patterns during a bilateral field-operational test including charging infrastructure and corresponding services (e.g. authentication, billing, roaming and reservations of public charging stations).

The model region of CROME is located in the French-German Upper Rhine Valley, between Karlsruhe in the north, Freiburg and Colmar in the south, Stuttgart in the east and the department Moselle in the west. Further details concerning the design of the CROME fleet test involving charging infrastructure and corresponding services can be found in [9].

The accompanying scientific research is conducted in an interdisciplinary manner. Computer scientists, energy economists, automotive engineers, jurisprudents and electrical engineers are working together in order to give responses to questions arising from different disciplinary origins. The acceptance analysis as part of the evaluation concept consists of repeatedly questioning the users and fleet managers of the EV by online surveys with different focuses (expectations, experiences and EV users' longterm adoption intentions), as well as of face-to face interviews with selected users (first results cf. [9]) and workshops for fleet managers. Additionally, technical data on trips such as speed, acceleration and GPS position but also trip purpose and payload is collected by using the vehicles' data loggers and additional smartphones (results available in [18]).

These data samples are anonymously reunited by a unique user ID what allows getting a comprehensive impression on EV users' experiences and potential anxieties concerning cross-border trips. By considering economic, sociological and cultural aspects in the acceptance study national particularities concerning EV user acceptance can be identified and potential barriers concerning transnational electric mobility, considering charging infrastructure and corresponding services as well as users' degree of satisfaction are analysed profoundly.

\subsection{Literature review on EV user acceptance}

Dütschke et al. [6] compare consumer acceptance of Liquefied Petroleum Gas (LPG) or Compressed Natural Gas (CNG) vehicles to $\mathrm{EV}$, as consumer perceptions might be similar. Interviewees reported that they had concerns regarding infrastructure and the reliability of the technology before using LPG and CNG cars. Conclusions from the study aim to derive recommendations on how to support the market penetration of EV. Concerns need to be overcome by improving the perceived reliability and safety of EV and it seems to be necessary that policy makers provide further incentives to start the ball rolling [10]. Wietschel et al. [21] identify early adopters of EV in Germany until 2020 on the basis of surveys and group discussions with EV users focusing on their economic, attitudinal and socio -demographic backgrounds. They indicate that the probability of privately purchasing an EV among current users of $\mathrm{EV}$ is highest for men in the beginning of their 40s, with a higher socio-economic status and most likely having a technical profession. This potential customer group is likely to live in multi person households with several vehicles, which tend to be in rural areas or in the outskirts. However, selling EV only to this group of early adopters will not be sufficient in order to reach the German political goal of one million EV until 2020.

Pierre et al. [19] base their analyses on about 40 semi-open interviews carried out between 2006 and 2008 each lasting about two hours intending to determine how EV are used within specific ways of life. The authors point out that all users agree on EVs' characteristics to be pleasant to drive and to be practical. Two groups of EV adopters are identified. On the one hand there are innovators characterized by a pioneering-ecological spirit, who like cutting edge technologies, who are sensible to the environment and who want to display and defend their values. On the other hand there are people who adopted EV by taking advantage of an opportunity (e.g. buying an EV from a company at a low price). Both groups agree on the fact that EV increase their sensitiveness to transport issues, to energy savings and to environmental questions. Interviewees mentioned that buying an $\mathrm{EV}$ was an obstacle and maintaining the EV was very difficult. Furthermore, the interviewees criticized 
the lack of public accessible charging infrastructure. The authors conclude that the presence of public accessible charging infrastructure is important in order to further develop electric mobility (also cf. [1]).

Windisch [22] tries to analyse the potential for EV demand in the region of Paris by using a disaggregate demand analysis based on socioeconomic data. Different scenarios of political and economic developments until 2023 are analysed in a model that has been constructed by taking the French National Transport Survey (ENTD) as data basis. A set of criteria like households' vehicle fleets, parking possibilities as well as vehicle usage patterns and Total Cost of Ownership (TCO) are considered. Conclusions indicate that fiscal measures that already have been launched in France, contribute to a large part to the economic advantage of EV over ICEV for some user patterns. Furthermore, providing public charging infrastructure appears to be an important lever. Scenario analyses indicate that maximal future demand for EV in the Paris region is in the range of $4-21 \%$ of households, what signifies an overall EV demand of 0.2 to 1 million vehicles until 2023. Peters et al. [16] describe that energy-relevant purchase decision of consumers can to a large extend be explained by psychological factors like attitudes towards more fuel-saving vehicles and awareness of problems related to fuel consumption. According to Peters et al. [17] psychological factors, such as attitudinal factors, beliefs, and motives, are relevant predictors of the fuel-efficiency of a chosen vehicle.

EV user acceptance has been analysed for France and Germany during several other studies (e.g. [5,23]). However, the cross-border fleet test CROME permits to identify national particularities concerning EV users' long-term experiences in France and Germany.

Based on the first online questionnaire within CROME focusing on EV users' expectations Ensslen et al. [7] have pointed out that user acceptance for EV is high for people living in rather rural French areas due to favorable TCO, a relaxed parking situation and a high average number of cars per household in small municipalities, which compensates for the range specific disadvantages most EV have. Annual mileage by car is on average higher for people living in small municipalities, which makes TCO favorable. Additionally French adopters benefit from EV purchase incentives (currently a purchase prime of 7,000 Euros) and from lower electricity costs (Average household prices in the second half of the year 2011 - France: 0.142 $€ / \mathrm{kWh}$; Germany: $0.253 € / \mathrm{kWh}$ [24]) which additionally decreases TCO for French EV adopters.

\section{Data and methods used}

Between September 2012 and May 2013 data has been collected by an online survey from 161 persons participating in CROME's fleet test. 95 of them stated to be only EV users, 11 of them only fleet managers and 49 of them stated to be both, fleet manager and EV user. Six of them did not answer this question.

The online questionnaires have been distributed in two languages, German and French, to persons who have experienced the EV on average for about a year. $21 \%$ of the users stated to use the EV every day or at least every workday, $21 \%$ indicated to use the EV one to three days per week, $34 \%$ of the users said to use it one to three days per month and $23 \%$ indicated to use it less than three days a month. None of the respondents answered to use it never or almost never.

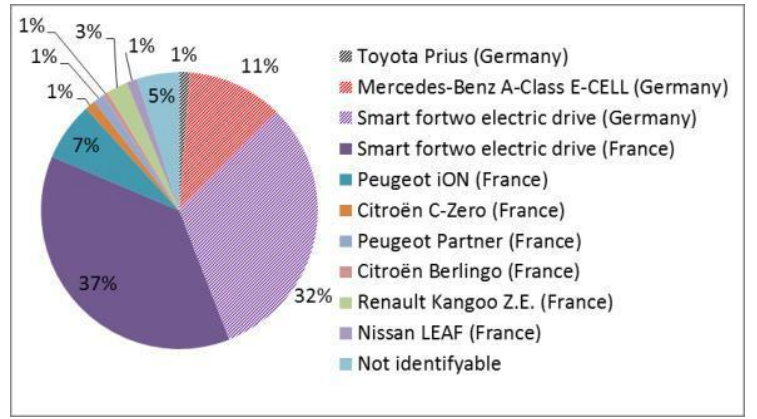

Figure 1: EV models the respondents have been using and their corresponding allocations $(n=161)$

Figure 1 visualizes the distribution of EV models the respondents have been using, illustrating that the majority of the survey participants (69\%) have been using the model Smart fortwo electric drive (Smart ED), $11 \%$ a Mercedes-Benz A-Class ECell, $8 \%$ a Peugeot iOn or a identically constructed Citroën C-Zero.

Figure 2 shows that the survey participants are predominantly working for public authorities (32\% of the survey participants work for French and 30\% for German public authorities). Another big part of the participants works for companies in the commercial sector $(18 \%$ of the respondents work for French and 14\% of the respondents for German businesses). Only $1 \%$ of the respondents were private users at this moment of the experimentation. 
More than $115 \mathrm{EV}$ are part of CROME's fleet test. It has been possible to convince respondents of 63 different EV to participate in the second online questionnaire. Due to the fact that the EV have mostly been used as pool cars in fleets, the sample has been increased accordingly.

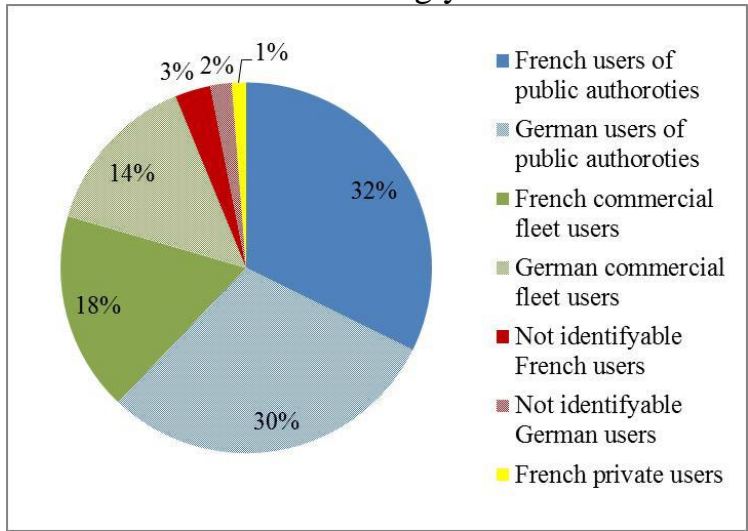

Figure 2: Users by country and sector $(n=161)$

Nevertheless, Figure 3 shows that for most of the EV (37) only one respondent could have been recruited and integrated in the sample, whereas $53 \%$ of the respondents have been using $12 \mathrm{EV}$ (i.e. four or more respondents per EV). Furthermore, the EV that have been used by four or more respondents are predominantly vehicles that have been allocated in Germany whereas EV that have been used by three respondents or less are predominantly allocated in France $(n=63$; $\left.\chi^{2}=12.799 ; \mathrm{df}=1 ; \mathrm{p}<0.001\right)$. According to fleet managers responding to the first questionnaire within CROME, companies with less than 100 employees are to a level of marginal significance overrepresented on the French side $(n=55$; $\left.\chi^{2}=3.107 ; \mathrm{df}=1 ; \mathrm{p}=0.078\right)$.

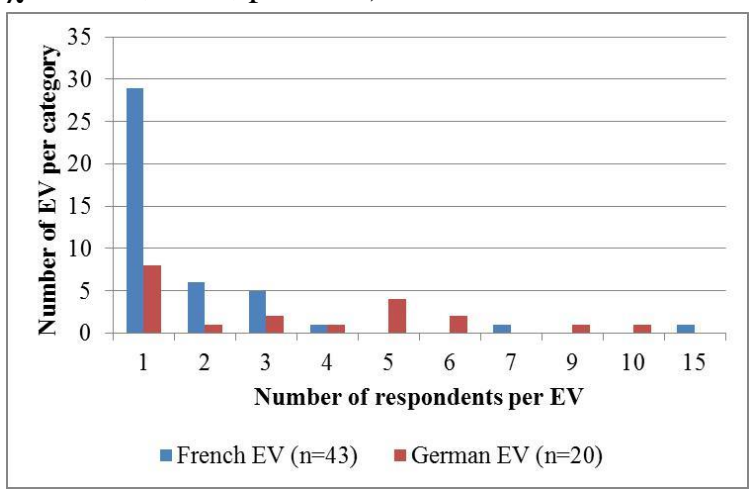

Figure 3: Number of EV and the corresponding number of respondents who have been using them $(n=63)$

The education level of CROME's users is high on the French as well as on the German side. About $63 \%$ of the respondents have at least an educational level of a Bachelor's degree (cf. Figure 4).

According to Figure 5 the majority of the French respondents either lives in small municipalities with less than 5,000 citizens or in cities with more than 100,000 citizens (notably Metz), whereas the German respondents predominantly live in small and big towns between 5,000 and 100,000 citizens (notably Baden-Baden and Rastatt).

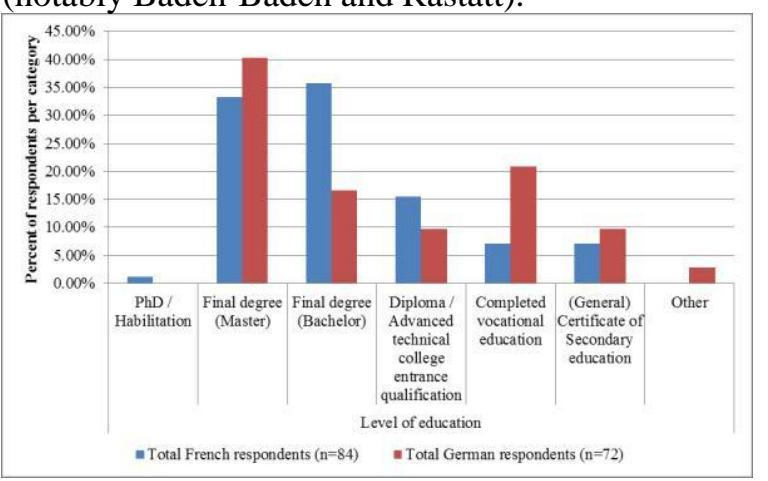

Figure 4: Respondents' level of education $(n=156)$

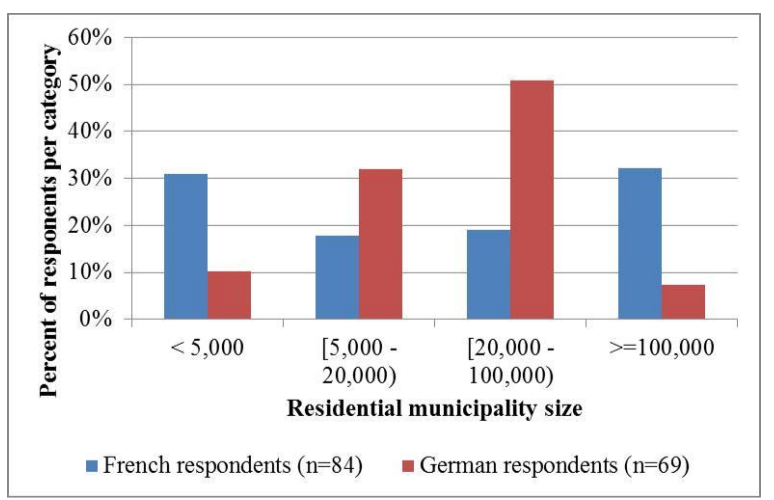

Figure 5: Respondents' residential municipality size by country $(n=153)$

As the major objective of the second online questionnaire has been to evaluate users' experiences with the EV, the respondents' degree of satisfaction with different characteristics of the EV has been measured. Additionally, respondents have been asked to evaluate different items measuring respondents' affinity towards innovations, their attitude towards $\mathrm{EV}$, their perception of EVs' public image, their environmental sensitivity as well as their price sensitivity. National and residential structure specific particularities have been focused on during the analyses.

In order to derive conclusions about respondents' individual attitudes and beliefs from the items measured, principal component analysis has been conducted with SPSS ${ }^{\circledR}$ according to Backhaus et al. [2]. 
In order to analyse and validate the findings statistically nonparametric Mann-Whitney Tests have been carried out.

The nonparametric statistical Mann-Whitney-Test is appropriate, because the evaluation of the items observing the respondents' degree of satisfaction with EVs' characteristics have been measured on an ordinal scale with four levels (completely satisfied, predominantly satisfied, predominantly not satisfied, not at all satisfied), so Gaussian distribution cannot be assumed (cf. [3]).

In order to conduct Mann-Whitney Tests [15] the following assumptions need to be fulfilled:

Two independent random variables $\mathrm{X}$ and $\mathrm{Y}$ have the continuous distributions $F X$ and $F Y$ characterized by the fact that they differ from each other only by an offset of $\alpha$.

$F_{y}(x)=F_{X}(x-\propto)$

The two independent samples have the characteristics $X_{1}, \ldots, X_{m}$ and $Y_{1}, \ldots, Y_{n}$. The following hypothesis is tested:

$H_{0}: \propto=0 \quad$ vs. $\quad H_{1}: \propto \neq 0$

Accordingly the test delivers significant results if the two samples have an offset (e.g. the French respondents evaluated an item different from the German).

In order to test this hypothesis Mann-Whitney-U statistic is calculated as follows:

$U=\sum_{i=1}^{m} \sum_{j=1}^{n} S\left(X_{i}, X_{j}\right)$

With

$S\left(X_{i}, X_{j}\right)= \begin{cases}1, & Y_{j}<X_{i} \\ & 0\end{cases}$

$\mathrm{U}$ can be approximated by a Gaussian distribution, if the sample's size is sufficiently big $(m>3, n>3$ and $\mathrm{m}+\mathrm{n}>19$ ).

$U \approx N\left(\frac{m n}{2} ; \frac{n m(n+m+1)}{12}\right)$

Accordingly the test's critical values are approximated by the critical values of the corresponding Gaussian distribution.

\section{Objectives}

The authors wanted to find out whether the findings of the first questionnaire focusing on EV users' expectations, determining that potential for $\mathrm{EV}$ diffusion is currently higher in rather rural French areas than in rather urbanized German regions is compatible with EV users' experiences, their attitudes and beliefs. Differences between the levels of satisfaction of German and French EV users as well as between the respondents living in municipalities with less than 20,000 citizens and more than 20,000 citizens are expected.
The authors wanted to find out whether EV users' affinity towards innovations, their worries about climate change impacts, their attitudes towards the EV themselves as well as the individuals' perceived social norm concerning the EV positively correlate with the EV users' overall degree of satisfaction.

\section{Results}

\subsection{EV users degree of satisfaction with different characteristics of $\mathbf{E V}$}

The respondents' overall degree of satisfaction with the EV is very high $(97 \%$ of the respondents answered being completely or predominantly satisfied). Furthermore, $76 \%$ of the respondents agreed to the statement to prefer driving an EV over driving a conventional car.

Based on the respondents' evaluations on satisfaction with different characteristics of the $\mathrm{EV}$, a cluster analysis has been performed and the respondents have been classified in two clusters representing respondents showing higher and lower degrees of satisfaction. Mann-Whitney Tests between the two clusters and EV users' evaluations on satisfaction with EVs' different characteristics show significant differences for all characteristics, but for sufficient range (cf. Table 1 in the Annexure). French users are more satisfied with EVs' characteristic to protect the climate by lower $\mathrm{CO}_{2}$-emissions to a highly significant degree ( $\mathrm{p}<$ $1 \%$, cf. Table 1 in the Annexure). The respondents seem to be aware of the electricity mix and corresponding $\mathrm{CO}_{2}$-emissions from fossil fuels consumed for electricity generation in France $(79 \mathrm{~g}$ $\mathrm{CO}_{2}$ per kWh in 2010) and Germany (about $461 \mathrm{~g}$ $\mathrm{CO} 2$ per $\mathrm{kWh}$ in 2010) [14]. German EV users are less satisfied with the EV maximum speed at a level of marginal significance $(\mathrm{p}<10 \%)$. Users' satisfaction has furthermore been analysed according to residential municipality size. Respondents living in municipalities with more than 20,000 citizens are to a highly significant degree $(p<1 \%)$ satisfied more with EVs' characteristic to emit no local emissions. Respondents who live in municipalities with more than 20,000 citizens are to a marginally significant degree $(\mathrm{p}<10 \%)$ satisfied more with EVs' range as well as the life cycle of their batteries as respondents living in municipalities with less than 20,000 citizens (cf. Table 1). 


\subsection{EV users' beliefs and attitudes}

Twenty items have been constructed in order to find out about the respondents' attitudes, beliefs and motives. Factors concerning respondents' affinity towards innovations, their general attitude towards EV, individuals perceived public image of $\mathrm{EV}$, their environmental sensitivity as well as their price sensitivity could have been derived by principal component analysis (cf. Table 2 in the Annexure). According to Backhaus et al. (2008) [2], Kaiser-Meyer -Olkin Measure of Sampling Adequacy of 0.80 is meritorious. As the results have reached the desirable level, the derived factors have been used during further analyses.

Observable dependencies between the respondents' country of origin and their attitudes have been analysed more profoundly. French respondents are in our sample to a highly significant degree $(\mathrm{p}<0.1 \%)$ more worried about climate change impacts and show to a significant level a higher affinity towards innovations ( $p<$ $5 \%$ ). Respondents' evaluations of items concerning EVs' corporate public image on the other hand indicate to a significant degree that the $\mathrm{EV}$ are more beneficial to the companies' public image in Germany than in France, so social norm of $\mathrm{EV}$ in the corporate context seems to be more crucial in Germany than in France. This is further supported by findings of the first online survey where fleet managers have been asked about the reasons why their companies have decided to purchase the EV (data collection period from September 2011 until April 2013). Prestige has to a significant degree been more likely to be mentioned by the German fleet managers being one of the three most important reasons to purchase an EV than by the French $\left(n=55 ; \chi^{2}=3.841 ; d f=1\right.$; $\mathrm{p}=0.05$ ).

Additionally, respondents classified in the cluster representing rather satisfied users tend to have a higher affinity towards innovations $(\mathrm{p}<10 \%)$ and tend to attach a higher degree of importance on the factor representing individuals' evaluations concerning the corporate public image of EV ( $p<$ $10 \%$ ) than the users who have been classified in the cluster with respondents who are less satisfied with the EV.

\subsection{Cross-border mobility with EV}

It needs to be considered that there is no need for cross-border trips in many of the respondents' companies and that interoperable public charging infrastructure was not set up in all parts of the model region during the period the survey has been carried out. Only 55 of $n=134$ respondents answering the questions about cross-border activity generally do cross-border trips (private or business trips with any means of transportation). Half of them (27) never use the EV for the crossborder trips, two multiple times a week, seven multiple times a month and 19 of them do so infrequently. $76 \%$ of these 55 persons state that average trip lengths of these cross-border trips are shorter than $100 \mathrm{~km} .7 \%$ indicate that average trip lengths are between $100 \mathrm{~km}$ and $150 \mathrm{~km}$. Overall only $16 \%$ indicate that trip lengths are bigger than $150 \mathrm{~km}$. Accordingly most of the cross-border trips effectively could be travelled with the EV even without charging. Nevertheless, several different reasons for users not to use EV for cross-border trips have been provided by the respondents who have been asked whether they have ever decided not to use the EV for these cross-border trips (cf. Figure 6).

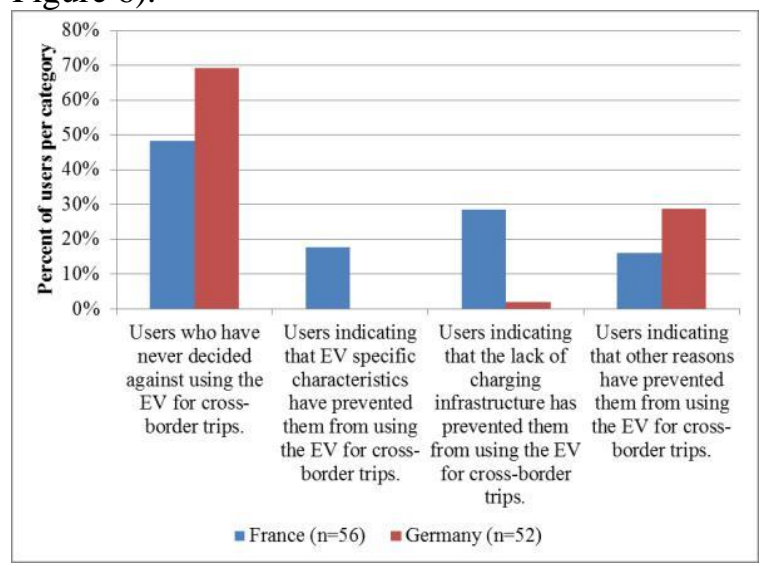

Figure 6: Have the users already decided against using the EV for cross-border trips? If yes, reasons for not using the EV for cross-border trips $(n=108)$

$69 \%$ of the German users indicated not actively having decided against using the EV for crossborder trips, whereas on the French side only $48 \%$ of the respondents said so. Accordingly differences between the answers are significant $(\mathrm{n}=108$; $\chi^{2}=4.9 ; \mathrm{df}=1 ; \mathrm{p}=0.026$ ). $18 \%$ of the French users answered that the specific characteristics of the EV have prevented them from using the EV for crossborder trips, notably that the range of the $\mathrm{EV}$ is not sufficient (100\% of the 10 French respondents who have chosen this option said so), that the EV is too slow (50\% of them said so) and that the EV didn't have enough seats (1 respondent). 17 respondents (16 French and 1 German) indicated that the lack of charging infrastructure was crucial to their decision not to use the EV for the cross-border trips at the point of time they responded to the survey. The 
respondents indicated that there has been no possibility to recharge the $\mathrm{EV}$ at their destination abroad (53\% of the 17 respondents said so) and that they have been afraid not to find adequate public charging stations for the EV on the other side of the border ( $77 \%$ of the 17 respondents said so). Furthermore, they stated that they have been afraid that the charging stations on the other side of the border would not have been compatible with their EV (47\% of them said so) and that they have been afraid that the public charging stations on the other side of the frontier would not be available at the point of time they would have been needed $(35 \%$ of them said so). This is further supported by respondents' indications not to charge the EV at public charging stations abroad (only 2 of the 82 respondents answering this question said to do so between 1 and 3 times a month, 75 indicated never charging abroad and 5 said that there is no possibility to do so). Other reasons not to use the EV for cross-border activity have been provided by 7 French and 15 German users, notably that they are not allowed to use the EV for cross-border trips ( $45 \%$ of the 22 respondents said so) and that they are not allowed to use the EV for private trips (41\%). Only one German person stated that the language barrier would be too high. Another reason is that the $\mathrm{EV}$ has not been disposable at the moment the user wanted to do the cross-border trip.

\subsection{Recommendations to further developments of cross-border mobility with EV}

In order to further analyse cross-border mobility with EV, the authors suggest allocating EV in company fleets or households who really have cross-border activity in the first place (like in the German showcase project RheinMobil [12]). Furthermore, the users should be allowed to use the EV for cross-border trips (especially the German users). As according to the users EVs' ranges and the lack of adequate charging infrastructure is restricting transnational trips, services which support the navigation process to localize charging stations as well as to make these services convenient and interoperable should be in focus, so the French EV drivers can access charging stations in Germany and vice-versa. CROME specific hardware- and software interoperable public charging infrastructure (cf.

[7] and [9]), has only been installed along the Rhine valley between Freiburg and Karlsruhe on the German side and in Moselle as well as in
Strasbourg on the French side [4]. As Saarland and Rhineland-Palatinate are not part of the CROME region, interoperable public charging infrastructure within EVs' range across the border is not available for EV users in Moselle. As the French respondents predominantly live in the region of Moselle [7] the authors strongly recommend according to the results presented in Figure 6 to further develop public accessible charging infrastructure interoperable in the crossborder context.

In order to make future cross-border activity with EV seamlessly possible and user friendly, norms and standards in the European context need to be defined and agreed on ensuring that hardware, software and corresponding services match with each other. Accordingly the European commission has released a proposal for a directive on the deployment of alternative fuels infrastructure [8] in January 2013 standardizing EV specific hardware components, notably plug-and-socket systems for Mode 3 and Mode 4 charging. The Type 2 plugand-socket system is preferred for the future European market to become the single standard for Mode 3 charging. Further standardisation, especially to ensure software interoperability and corresponding services (authentication, billing, reservation etc.) still needs to be done. CROME demonstrates the current challenges and provides first suggestions for future resolutions in the European context (cf. GreenEmotion [11] and Hubject [13]). After a finalisation of the standardisation process our results recommend to actively promote and communicate the availability of customer-friendly public accessible interoperable charging infrastructure to $\mathrm{EV}$ users in order to overcome their prejudices with respect to the charging processes abroad.

\subsection{Constraints}

It should be critically acclaimed that the results which can be derived from the CROME field test are neither representative for France nor for Germany, as our sample do not represent the corresponding population. E.g. our respondents are predominantly male and their household incomes as well as their educational levels are above average. Furthermore, double-seaters (Smart ED) are overrepresented in our analysis (share of $58.7 \%$ ). These $\mathrm{n}=37$ Smart ED have been used by $69 \%$ of the respondents . Therefore, the user satisfaction, e.g. concerning vehicle size and speed might refer to this disparity. 


\section{Conclusion}

The main research questions asking about potentials for EV diffusion in France and Germany as well as for potentials in rather urbanized and rather rural areas has been evaluated by distributing online questionnaires to EV users who have experienced EV on average for a year.

Results indicate that French users are satisfied more with the EVs' characteristics to protect the environment by low $\mathrm{CO}_{2}$ emissions and the EVs' maximum speed. As $\mathrm{CO}_{2}$ emissions from electricity generation are indeed lower in France, differences in users' evaluations are perspicuous. As speed limits in France are more restrictive than in Germany and the Smart EDs' maximum speed is limited to $100 \mathrm{~km} / \mathrm{h}$ [4], users' analogue evaluations in this context are perspicuous, too.

Furthermore, attitudinal variables have been examined. The French respondents show a higher affinity towards innovations and they are more worried about climate change impacts. The German respondents on the other hand indicate to a higher degree that the EV are favorable for their companies' corporate public image. Prestige is more likely being a reason to purchase $\mathrm{EV}$ in Germany than in France.

Furthermore, results indicate that respondents living in municipalities with more than 20,000 citizens are more satisfied with the EVs' characteristics as e.g. absence of local emissions and to have sufficient range and battery lifetime. Additionally, respondents living in municipalities with more than 20,000 citizens are more worried about future impacts of climate change. Accordingly convincing them to use EV could be easier than in rather rural areas. As the major part of the urban dwellers might not be willing to purchase EV currently, carsharing with EV should be further developed in urbanized areas (also cf. [7]). Accordingly, the authors conclude that potential for market penetration of $\mathrm{EV}$ in urban areas is not necessarily worse than in rather rural areas (cf. [7]).

Not surprisingly, the users which have been classified in the cluster representing the respondents showing a higher degree of satisfaction with EVs' different characteristics have a higher affinity towards innovations and tend to higher evaluate the public corporate image of EV. According to Rogers' theory concerning diffusion of innovations [20] the authors assume that EV adoption potential amongst others depends on the factors concerning individuals' perceived social norm of EV, their attitude towards $\mathrm{EV}$ as well as their affinity towards innovations (also cf. [16, 17]). As the French users' individual affinity towards innovations is significantly higher whereas the German users' evaluations concerning EVs' public corporate image are significantly higher, the authors assume that potential for widespread diffusion of EV might be currently somewhat higher in France. On the other hand EVs' very positive corporate public image in Germany might be a decisive factor permitting to allocate EV in commercial or public authorities' fleets.

In order to facilitate carsharing with $\mathrm{EV}$ and to make it user friendly, a 'system backbone' that manages communication between different market participants (e.g. users, carsharing providers, charging service providers) should be established in order to integrate different service providers' systems and to offer interoperable solutions. CROME demonstrates that interoperable solutions for BEV specific charging services are possible, even in the cross-border context. After a finalisation of the standardisation process availability of customer-friendly public accessible interoperable charging infrastructure should be promoted actively to $\mathrm{EV}$ users in order to overcome their prejudices with respect to the charging processes abroad.

\section{Outlook}

In order to evaluate whether EV users' experiences impact their perceptions of EV, evaluations from individuals representing persons who did not experience EV should be compared to the CROME samples. Furthermore, the respondents' willingness to further adopt $\mathrm{EV}$ including future usage intentions and private purchase decisions after a longer period of experiencing EV should be evaluated. Importance of different e-mobility services and charging tariffs as well as EV users' corresponding willingness to pay should be analysed in order to derive conclusions about profitability potentials of stakeholders'strategies and potential business cases.

Furthermore, objective user specific trip data that have been measured with data loggers in the EV should be reunited with subjective, user-specific data originating from the online questionnaires in order to test whether individuals' driving behaviours correlate with their socio-demographic backgrounds and their degrees of satisfaction with different EV specific characteristics. 


\section{Appendix}

Table 1: Results of Mann-Whitney tests between users' evaluations concerning degrees of satisfaction with EVs' different characteristics, their residential municipality size and nationality

Scale for measuring respondents' degree of satisfaction:

1: Completely satisfied |2: Predominantly satisfied |3: Predominantly not satisfied |4: Not at all satisfied

\begin{tabular}{|c|c|c|c|c|c|c|c|c|c|c|c|}
\hline Items & $\begin{array}{l}\text { Residential } \\
\text { municipality } \\
\text { size }\end{array}$ & $\mathbf{n}$ & $\begin{array}{l}\text { Mean } \\
\text { Rank }\end{array}$ & $\begin{array}{c}\text { p- } \\
\text { value }\end{array}$ & $\begin{array}{l}\text { Users' } \\
\text { country }\end{array}$ & $\mathbf{n}$ & $\begin{array}{l}\text { Mean p- } \\
\text { Rank value }\end{array}$ & \begin{tabular}{|l|} 
Degree \\
of \\
satis- \\
faction
\end{tabular} & $\mathbf{n}$ & $\begin{array}{l}\text { Mean } \\
\text { Rank }\end{array}$ & $\begin{array}{c}\text { p- } \\
\text { value }\end{array}$ \\
\hline $\begin{array}{l}\text { Are you generally } \\
\text { satisfied with the } \\
\text { electric car? }\end{array}$ & $\begin{array}{l}<20,000 \\
>=20,000\end{array}$ & $\begin{array}{l}65 \\
74\end{array}$ & $\begin{array}{l}70.14 \\
69.88\end{array}$ & 0.965 & $\begin{array}{l}\text { France } \\
\text { Germany }\end{array}$ & $\begin{array}{l}80 \\
66\end{array}$ & $\begin{array}{l}68.98 \\
78.980 .102\end{array}$ & $\begin{array}{l}\text { Higher } \\
\text { Lower }\end{array}$ & $\begin{array}{l}47 \\
68\end{array}$ & $\begin{array}{l}46.76 \\
65.77\end{array}$ & 0.001 \\
\hline $\begin{array}{l}\text { Climate protection by } \\
\text { low } \mathrm{CO}_{2} \text { emissions }\end{array}$ & $\begin{array}{l}<20,000 \\
>=20,000\end{array}$ & $\begin{array}{l}63 \\
71\end{array}$ & $\begin{array}{l}70.71 \\
64.65\end{array}$ & 0.232 & $\begin{array}{l}\text { France } \\
\text { Germany }\end{array}$ & $\begin{array}{l}78 \\
63\end{array}$ & $\begin{array}{l}63.35 \\
80.48 \mathbf{0 . 0 0 1}\end{array}$ & $\begin{array}{l}\text { Higher } \\
\text { Lower }\end{array}$ & $\begin{array}{l}47 \\
68\end{array}$ & $\begin{array}{l}51.06 \\
62.79\end{array}$ & 0.016 \\
\hline No 1 & $\begin{array}{l}<20,000 \\
>=20,000\end{array}$ & $\begin{array}{l}62 \\
72\end{array}$ & $\begin{array}{l}73.13 \\
62.65\end{array}$ & 0.010 & $\begin{array}{l}\text { France } \\
\text { Germany }\end{array}$ & $\begin{array}{l}78 \\
63\end{array}$ & $\begin{array}{l}71.35 \\
70.570 .856\end{array}$ & $\begin{array}{l}\text { Higher } \\
\text { Lower }\end{array}$ & $\begin{array}{l}47 \\
68\end{array}$ & $\begin{array}{l}53.89 \\
60.84\end{array}$ & 0.081 \\
\hline High & $\begin{array}{l}<20,000 \\
>=20,000\end{array}$ & $\begin{array}{l}65 \\
73\end{array}$ & $\begin{array}{l}72.21 \\
67.09\end{array}$ & 0.396 & $\begin{array}{l}\text { France } \\
\text { Germany }\end{array}$ & $\begin{array}{l}79 \\
65\end{array}$ & $\begin{array}{l}68.85 \\
76.930 .192\end{array}$ & $\begin{array}{l}\text { Higher } \\
\text { Lower }\end{array}$ & $\begin{array}{l}47 \\
68\end{array}$ & $\begin{array}{l}38.26 \\
71.65\end{array}$ & 0.000 \\
\hline Good ac & $\begin{array}{l}<20,000 \\
>=20,000\end{array}$ & $\begin{array}{l}63 \\
73\end{array}$ & $\begin{array}{l}68.53 \\
68.47\end{array}$ & 0.992 & $\begin{array}{l}\text { France } \\
\text { Germany }\end{array}$ & $\begin{array}{l}78 \\
64\end{array}$ & $\begin{array}{l}72.13 \\
70.730 .825\end{array}$ & $\begin{array}{l}\text { Higher } \\
\text { Lower }\end{array}$ & $\begin{array}{l}47 \\
68\end{array}$ & $\begin{array}{l}30.17 \\
77.24\end{array}$ & 0.000 \\
\hline $\begin{array}{l}\text { Adequate maximum } \\
\text { speed }\end{array}$ & $\begin{array}{l}<20,000 \\
>=20,000\end{array}$ & $\begin{array}{l}64 \\
74\end{array}$ & $\begin{array}{l}70.48 \\
68.65\end{array}$ & 0.769 & $\begin{array}{l}\text { France } \\
\text { Germany }\end{array}$ & & $\begin{array}{l}66.48 \\
80.03 \mathbf{0 . 0 3 4}\end{array}$ & $\begin{array}{l}\text { Higher } \\
\text { Lower }\end{array}$ & $\begin{array}{l}47 \\
68\end{array}$ & $\begin{array}{l}32.12 \\
75.89\end{array}$ & 0.000 \\
\hline comfort & $\begin{array}{l}<20,000 \\
>=20,000\end{array}$ & $\begin{array}{l}61 \\
72\end{array}$ & $\begin{array}{l}69.34 \\
65.02\end{array}$ & 0.468 & $\begin{array}{l}\text { France } \\
\text { Germany }\end{array}$ & $\begin{array}{l}79 \\
60\end{array}$ & $\begin{array}{l}67.78 \\
72.930 .399\end{array}$ & $\begin{array}{l}\text { Higher } \\
\text { Lower }\end{array}$ & $\begin{array}{l}47 \\
68\end{array}$ & $\begin{array}{l}34.18 \\
74.46\end{array}$ & 0.000 \\
\hline iving sound & $\begin{array}{l}<20,000 \\
>=20,000\end{array}$ & $\begin{array}{l}65 \\
74\end{array}$ & $\begin{array}{l}70.35 \\
69.70\end{array}$ & 0.910 & $\begin{array}{l}\text { France } \\
\text { Germany }\end{array}$ & $\begin{array}{l}80 \\
66\end{array}$ & $\begin{array}{l}71.54 \\
75.870 .465\end{array}$ & $\begin{array}{l}\text { Higher } \\
\text { Lower }\end{array}$ & $\begin{array}{l}47 \\
68\end{array}$ & $\begin{array}{l}47.28 \\
65.41\end{array}$ & 0.000 \\
\hline $\begin{array}{l}\text { High safety when } \\
\text { driving }\end{array}$ & $\begin{array}{l}<20,000 \\
>=20,000\end{array}$ & $\begin{array}{l}63 \\
72\end{array}$ & $\begin{array}{l}71.87 \\
64.61\end{array}$ & 0.198 & $\begin{array}{l}\text { France } \\
\text { Germany }\end{array}$ & $\begin{array}{l}78 \\
63\end{array}$ & $\begin{array}{l}73.87 \\
67.450 .268\end{array}$ & $\begin{array}{l}\text { Higher } \\
\text { Lower }\end{array}$ & $\begin{array}{l}47 \\
68\end{array}$ & $\begin{array}{l}41.07 \\
69.70\end{array}$ & 0.000 \\
\hline $\begin{array}{l}\text { High safety when } \\
\text { charging }\end{array}$ & $\begin{array}{l}<20,000 \\
>=20,000\end{array}$ & $\begin{array}{l}63 \\
69\end{array}$ & $\begin{array}{l}69.82 \\
63.47\end{array}$ & 0.279 & $\begin{array}{l}\text { France } \\
\text { Germany }\end{array}$ & $\begin{array}{l}74 \\
64\end{array}$ & $\begin{array}{l}65.42 \\
74.220 .145\end{array}$ & $\begin{array}{l}\text { Higher } \\
\text { Lower }\end{array}$ & $\begin{array}{l}47 \\
67\end{array}$ & $\begin{array}{l}38.54 \\
70.80\end{array}$ & 0.000 \\
\hline $\begin{array}{l}\text { Reliability of the } \\
\text { vehicle }\end{array}$ & $\begin{array}{l}<20,000 \\
>=20,000\end{array}$ & $\begin{array}{l}64 \\
70\end{array}$ & $\begin{array}{l}70.39 \\
64.86\end{array}$ & 0.354 & $\begin{array}{l}\text { France } \\
\text { Germany }\end{array}$ & $\begin{array}{l}76 \\
63\end{array}$ & $\begin{array}{l}74.59 \\
64.47 \mathbf{0 . 0 9 6}\end{array}$ & $\begin{array}{l}\text { Higher } \\
\text { Lower }\end{array}$ & $\begin{array}{l}47 \\
68\end{array}$ & $\begin{array}{l}43.74 \\
67.85\end{array}$ & 0.000 \\
\hline $\begin{array}{l}\text { Good service (Help } \\
\text { with technical } \\
\text { problems) }\end{array}$ & $\begin{array}{l}<20,000 \\
>=20,000\end{array}$ & $\begin{array}{l}47 \\
49\end{array}$ & $\begin{array}{l}48.06 \\
48.92\end{array}$ & 0.859 & $\begin{array}{l}\text { France } \\
\text { Germany }\end{array}$ & $\begin{array}{l}50 \\
49\end{array}$ & $\begin{array}{l}51.03 \\
48.950 .672\end{array}$ & $\begin{array}{l}\text { Higher } \\
\text { Lower }\end{array}$ & $\begin{array}{l}40 \\
49\end{array}$ & $\begin{array}{l}39.39 \\
49.58\end{array}$ & 0.029 \\
\hline $\mathrm{Su}$ & $\begin{array}{l}<20,000 \\
>=20,000\end{array}$ & $\begin{array}{l}64 \\
70\end{array}$ & $\begin{array}{l}72.99 \\
62.48\end{array}$ & 0.090 & $\begin{array}{l}\text { France } \\
\text { Germany }\end{array}$ & $\begin{array}{l}77 \\
62\end{array}$ & $\begin{array}{l}70.16 \\
69.810 .956\end{array}$ & $\begin{array}{l}\text { Higher } \\
\text { Lower }\end{array}$ & $\begin{array}{l}47 \\
68\end{array}$ & $\begin{array}{l}53.21 \\
61.31\end{array}$ & 0.164 \\
\hline $\begin{array}{l}\text { Sufficient life cycle of } \\
\text { the battery }\end{array}$ & $\begin{array}{l}<20,000 \\
>=20,000\end{array}$ & $\begin{array}{l}41 \\
39\end{array}$ & $\begin{array}{l}44.35 \\
36.45\end{array}$ & 0.078 & $\begin{array}{l}\text { France } \\
\text { Germany }\end{array}$ & $\begin{array}{l}43 \\
39\end{array}$ & $\begin{array}{l}40.17 \\
42.960 .537\end{array}$ & $\begin{array}{l}\text { Higher } \\
\text { Lower }\end{array}$ & $\begin{array}{l}32 \\
40\end{array}$ & $\begin{array}{l}31.25 \\
40.70\end{array}$ & 0.027 \\
\hline Sufficient trunk space & $\begin{array}{l}<20,000 \\
>=20,000\end{array}$ & $\begin{array}{l}63 \\
68\end{array}$ & $\begin{array}{l}66.10 \\
65.91\end{array}$ & 0.976 & $\begin{array}{l}\text { France } \\
\text { Germany }\end{array}$ & $\begin{array}{l}74 \\
64\end{array}$ & $\begin{array}{l}69.12 \\
69.940 .896\end{array}$ & $\begin{array}{l}\text { Higher } \\
\text { Lower }\end{array}$ & $\begin{array}{l}47 \\
68\end{array}$ & $\begin{array}{l}44.87 \\
67.07\end{array}$ & 0.000 \\
\hline $\begin{array}{l}\text { Safety of other road } \\
\text { users when } \\
\text { approaching noiseless }\end{array}$ & $\begin{array}{l}<20,000 \\
>=20,000\end{array}$ & $\begin{array}{l}59 \\
63\end{array}$ & $\begin{array}{l}59.03 \\
63.81\end{array}$ & 0.383 & $\begin{array}{l}\text { France } \\
\text { Germany }\end{array}$ & $\begin{array}{l}68 \\
60\end{array}$ & $\begin{array}{l}63.40 \\
65.740 .677\end{array}$ & $\begin{array}{l}\text { Higher } \\
\text { Lower }\end{array}$ & $\begin{array}{l}44 \\
62\end{array}$ & $\begin{array}{l}46.51 \\
58.46\end{array}$ & 0.020 \\
\hline
\end{tabular}


Table 2: Results of principal component analysis

\begin{tabular}{|c|c|c|c|c|c|c|c|}
\hline & \multicolumn{5}{|c|}{ Rotated Component Matrix $^{\mathrm{a}}$} & \multirow{3}{*}{$\begin{array}{l}\text { Commu- } \\
\text { nalities }\end{array}$} & \multirow{3}{*}{$\begin{array}{c}\text { Measures } \\
\text { of } \\
\text { sampling } \\
\text { adequacy } \\
\text { (MSA) }\end{array}$} \\
\hline & \multicolumn{5}{|c|}{ Component } & & \\
\hline & $1^{\mathrm{b}}$ & $2^{c}$ & $3^{\mathrm{d}}$ & $4^{e}$ & $5^{\mathrm{f}}$ & & \\
\hline $\begin{array}{l}\text { It worries me when I think about the environmental } \\
\text { conditions under which our children and } \\
\text { grandchildren will probably have to live. }\end{array}$ & 0.14 & 0.11 & 0.16 & 0.80 & 0.11 & 0.71 & 0.78 \\
\hline $\begin{array}{l}\text { If we continue with business as usual, we are } \\
\text { heading towards an environmental catastrophe. }\end{array}$ & 0.01 & 0.05 & 0.04 & 0.87 & 0.01 & 0.75 & 0.73 \\
\hline $\begin{array}{l}\text { The citizens can make significant contributions to } \\
\text { climate protection by environmentally conscious } \\
\text { everyday behavior. }\end{array}$ & 0.06 & 0.17 & 0.11 & 0.81 & 0.05 & 0.71 & 0.74 \\
\hline I am very excited about technologies & 0.71 & 0.28 & 0.08 & 0.02 & 0.11 & 0.61 & 0.83 \\
\hline $\begin{array}{l}\text { I constantly do research on new technical } \\
\text { developments. }\end{array}$ & 0.81 & 0.24 & 0.06 & 0.11 & 0.12 & 0.75 & 0.86 \\
\hline $\begin{array}{l}\text { I like to try new products and technical innovations, } \\
\text { even if they are not yet as widespread. }\end{array}$ & 0.82 & 0.20 & 0.14 & 0.13 & 0.00 & 0.74 & 0.86 \\
\hline $\begin{array}{l}\text { I often look for information about new products and } \\
\text { brands. }\end{array}$ & 0.87 & 0.01 & 0.17 & 0.10 & 0.09 & 0.80 & 0.82 \\
\hline $\begin{array}{l}\text { I am often one of the first persons in my circle of } \\
\text { friends and acquaintances, who is getting new } \\
\text { technologies as soon as they appear on the market. }\end{array}$ & 0.81 & -0.02 & 0.12 & -0.05 & 0.01 & 0.67 & 0.78 \\
\hline $\begin{array}{l}\text { When I purchase products I compare them first and } \\
\text { then buy the cheapest. }\end{array}$ & 0.08 & -0.09 & 0.07 & 0.00 & 0.84 & 0.73 & 0.50 \\
\hline $\begin{array}{l}\text { When I buy a product I always try to buy the } \\
\text { maximum quality at the lowest possible price. }\end{array}$ & 0.12 & 0.19 & -0.05 & 0.15 & 0.72 & 0.60 & 0.71 \\
\hline Using the electric car is easy & 0.13 & 0.75 & 0.12 & 0.21 & 0.03 & 0.63 & 0.81 \\
\hline The electric car is useful in everyday life. & 0.09 & 0.86 & 0.15 & 0.09 & -0.02 & 0.78 & 0.78 \\
\hline The electric car is environmentally friendly. & 0.12 & 0.28 & 0.52 & 0.14 & 0.23 & 0.43 & 0.85 \\
\hline The electric car excites me. & 0.18 & 0.80 & 0.24 & 0.05 & 0.00 & 0.73 & 0.77 \\
\hline $\begin{array}{l}\text { I prefer driving an electric car to driving a } \\
\text { conventional car. }\end{array}$ & 0.17 & 0.74 & 0.19 & 0.06 & 0.12 & 0.63 & 0.78 \\
\hline $\begin{array}{l}\text { The use of electric car is good for the company's } \\
\text { image. }\end{array}$ & 0.07 & 0.11 & 0.79 & 0.06 & 0.23 & 0.71 & 0.81 \\
\hline $\begin{array}{l}\text { My colleagues / employees think it is good, that we } \\
\text { use electric cars. }\end{array}$ & 0.07 & 0.17 & 0.68 & 0.05 & -0.18 & 0.54 & 0.79 \\
\hline $\begin{array}{l}\text { By using electric cars our company adopts a } \\
\text { pioneering role. }\end{array}$ & 0.12 & 0.14 & 0.81 & 0.02 & -0.01 & 0.70 & 0.84 \\
\hline $\begin{array}{l}\text { Our company is interested in that innovations like } \\
\text { the electric car establish themselves on the market. }\end{array}$ & 0.19 & 0.12 & 0.73 & 0.17 & -0.10 & 0.62 & 0.81 \\
\hline \multicolumn{8}{|c|}{$\begin{array}{l}\text { Extraction Method: Principal Component Analysis. } \\
\text { Rotation Method: Varimax with Kaiser Normalization. }\end{array}$} \\
\hline $\begin{array}{l}\text { a. Rotation converged in } 5 \text { iterations. | b. Factor } 1 \text { : } \\
\text { EV |d. Factor 3: Public image of the EV | e. Factor } \\
\text { Price sensitivity }\end{array}$ & nity & 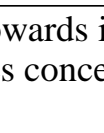 & 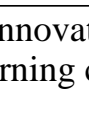 & 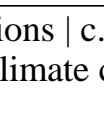 & 7 & : Atti & owards \\
\hline
\end{tabular}


Table 3: Results of Mann-Whitney tests between users' attitudes and their degree of satisfaction with EVs' charactersitics, their residential municipality size and nationality

Scale on which items considered during principal component analysis have been measured:

1: Strongly agree |2: Agree |3: Agree somewhat |4: Rather disagree |5: Disagree |6: Strongly disagree

\begin{tabular}{|c|c|c|c|c|c|c|c|c|c|c|c|c|}
\hline Factors & $\begin{array}{l}\text { Residential } \\
\text { municipality } \\
\text { size }\end{array}$ & $\mathbf{n}$ & $\begin{array}{c}\text { Mean } \\
\text { rank }\end{array}$ & $\begin{array}{c}\text { p- } \\
\text { value }\end{array}$ & $\begin{array}{l}\text { Users' } \\
\text { country }\end{array}$ & $\mathbf{n}$ & $\begin{array}{c}\text { Mean } \\
\text { rank } \\
\end{array}$ & $\begin{array}{c}\text { p- } \\
\text { value }\end{array}$ & \begin{tabular}{|l|} 
Degree \\
of \\
satis- \\
faction \\
\end{tabular} & $\mathbf{n}$ & $\begin{array}{c}\text { Mean } \\
\text { rank }\end{array}$ & $\begin{array}{c}\text { p- } \\
\text { value }\end{array}$ \\
\hline $\begin{array}{l}\text { Affinity towards } \\
\text { innovations }\end{array}$ & $\begin{array}{l}<20,000 \\
>=20,000\end{array}$ & $\begin{array}{l}70 \\
83\end{array}$ & $\begin{array}{l}77.82 \\
76.31\end{array}$ & 0.833 & $\begin{array}{l}\text { France } \\
\text { Germany }\end{array}$ & $\begin{array}{l}87 \\
74\end{array}$ & $\begin{array}{l}72.57 \\
90.91\end{array}$ & 0.013 & $\begin{array}{l}\text { Higher } \\
\text { Lower }\end{array}$ & $\begin{array}{l}47 \\
68\end{array}$ & $\begin{array}{l}50.98 \\
62.85\end{array}$ & 0.060 \\
\hline $\begin{array}{l}\text { Attitude towards the } \\
\text { EV }\end{array}$ & $\begin{array}{l}<20,000 \\
>=20,000\end{array}$ & $\begin{array}{l}70 \\
83\end{array}$ & $\begin{array}{l}74.08 \\
79.46\end{array}$ & 0.454 & $\begin{array}{l}\text { France } \\
\text { Germany }\end{array}$ & $\begin{array}{l}87 \\
74\end{array}$ & $\begin{array}{l}76.69 \\
86.07\end{array}$ & 0.203 & $\begin{array}{l}\text { Higher } \\
\text { Lower }\end{array}$ & $\begin{array}{l}47 \\
68\end{array}$ & $\begin{array}{l}43.21 \\
68.22\end{array}$ & 0.000 \\
\hline $\begin{array}{l}\text { Public corporate image } \\
\text { of the EV }\end{array}$ & $\begin{array}{l}<20,000 \\
>=20,000\end{array}$ & $\begin{array}{l}70 \\
83\end{array}$ & $\begin{array}{l}76.06 \\
77.79\end{array}$ & 0.810 & $\begin{array}{l}\text { France } \\
\text { Germany }\end{array}$ & $\begin{array}{l}87 \\
74\end{array}$ & $\begin{array}{l}88.52 \\
72.16\end{array}$ & 0.027 & $\begin{array}{l}\text { Higher } \\
\text { Lower }\end{array}$ & $\begin{array}{l}47 \\
68\end{array}$ & $\begin{array}{l}51.32 \\
62.62\end{array}$ & 0.074 \\
\hline $\begin{array}{l}\text { Worries concerning } \\
\text { climate change impacts }\end{array}$ & $\begin{array}{l}<20,000 \\
>=20,000\end{array}$ & $\begin{array}{l}70 \\
83\end{array}$ & $\begin{array}{l}85.06 \\
70.20 \\
\end{array}$ & $\mathbf{0 . 0 3 9}$ & $\begin{array}{l}\text { France } \\
\text { Germany }\end{array}$ & $\begin{array}{l}87 \\
74\end{array}$ & $\begin{array}{r}64.48 \\
100.42 \\
\end{array}$ & 0.000 & $\begin{array}{l}\text { Higher } \\
\text { Lower }\end{array}$ & $\begin{array}{l}47 \\
68\end{array}$ & $\begin{array}{l}54.49 \\
60.43\end{array}$ & 0.348 \\
\hline Price Sensitivity & $\begin{array}{l}<20,000 \\
>=20,000\end{array}$ & $\begin{array}{l}70 \\
83\end{array}$ & $\begin{array}{l}72.28 \\
80.98\end{array}$ & 0.226 & $\begin{array}{l}\text { France } \\
\text { Germany }\end{array}$ & $\begin{array}{l}87 \\
74\end{array}$ & $\begin{array}{l}84.33 \\
77.08\end{array}$ & 0.325 & $\begin{array}{l}\text { Higher } \\
\text { Lower }\end{array}$ & $\begin{array}{l}47 \\
68\end{array}$ & $\begin{array}{l}61.09 \\
55.87\end{array}$ & 0.409 \\
\hline
\end{tabular}

\section{Acknowledgments}

We would like to thank Anne-Sophie Fulda, Magali Pierre, Sonja Babrowski, Alexandra-Gwyn Paetz and Johannes Schäuble for their substantial support during the development phases of the online questionnaires as well as for their helpful comments for this paper. This research was made possible by the CROME project [ref. no. 01ME12002], funded by the Federal Ministry of Economics and Technology (BMWi), the Federal Ministry of Transport, Building and Urban Affairs (BMVBS) and the French programme Investissements d'avenir programme véhicule de futur.

\section{References}

[1] Achtnicht, M., Bühler, G., Hermeling, C., 2012. The impact of fuel availability on demand for alternative-fuel vehicles. Transportation Research Part D, 17, 262-269.

[2] Backhaus, K., Erichson, B., Plinke, W., Weiber, R., 2008. Multivariate Analysemethoden. Heidelberg. (ISBN 978-3642-16490-3).

[3] Bortz, J., 2005. Statistik für Human- und Sozialwissenschaftler. Heidelberg. (ISBN 978-3-540-21271-3).
[4] CROME Website, http://crome-project.eu, accessed on 2013-06-12.

[5] Dütschke, E., Schneider, U., Sauer, A., Wietschel, M., Hoffmann, J., 2011. Roadmap zur Kundenakzeptanz, Karlsruhe.

[6] Dütschke, E., Schneider, U., Peters, A., Paetz, A., Jochem, P., 2011. Moving towards more efficient car use - what can be learnt about consumer acceptance from analysing the cases of LPG and CNG, ECEEE 2011 Summer Study Proceedings.

[7] Ensslen, A., Jochem, P., Schäuble, J., Babrowski, S., Fichtner, W., 2013. User acceptance of electric vehicles in the FrenchGerman transnational context, in selected proceedings of the $13^{\text {th }}$ WCTR, Rio de Janeiro.

[8] European Commission, 2013, Proposal for a DIRECTIVE OF THE EUROPEAN PARLIAMENT AND OF THE COUNCIL on the deployment of alternative fuels infrastructure, Brussels. http://eurlex.europa.eu/LexUriServ/LexUriServ.do?ur $\mathrm{i}=\mathrm{COM}: 2013: 0018: F I N: E N: P D F$.

[9] Gagnol, P., Jochem, P., Fichtner, W., 2013. CROME: the French and German Field Demonstration of the Interoperable Mobility with EVs, Proceedings of EVS27.

[10] Gomez-Vilchez, J., Jochem, P., Fichtner, W., 2013, THE IMPACT OF ELECTRIC VEHICLES ON THE GLOBAL OIL 
DEMAND AND CO2 EMISSIONS, submitted to WCTR 2013, Rio de Janeiro, Brazil.

[11] Green Emotion Project's website, http://www.greenemotion-project.eu/, accessed on 2013-06-05.

[12] Hofacker, A., 2013. Projekt RheinMobil: Geld sparen mit Elektromobilität, http://www.springerprofessional.de/projektrheinmobil-geld-sparen-mit-

elektromobilitaet/4015764.html, accessed on 2013-06-14.

[13] Hubject website, www.hubject.com/, accessed on 2013-06-10.

[14] International Energy Agency (IEA), 2012. $\mathrm{CO}_{2}$ emissions from fuel combustion, http://www.iea.org/co2highlights/co2highlig hts.pdf, accessed on 2013-06-17.

[15] Mann, H., Whitney, D., 1947. On a test of whether one of two random variables is stochastically larger than the other. Annals of mathematical Statistics 18, 50-60.

[16] Peters, A., de Haan, P., Scholz, W., 2013. Understanding Car Buying Behavior: Psychological Determinants of Energy Efficiency and Practical Implications, International Journal of Sustainable Transportation.

[17] Peters, A., Gutscher, H., Scholz, W., 2011. Psychological determinants of fuel consumption of purchased new cars, Transportation Research Part F 14, 229-239.

[18] Pfriem, M., Gauterin, F., 2013. Less range as a possible solution for the market success of electric vehicles in commercial fleets, Proceedings of EVS27.

[19] Pierre, M., Jemelin, C., Louvet, N., 2011. Driving an electric vehicle. A sociological analysis on pioneer users. Energy Efficiency, Volume 4, Issue 4, 511-522.

[20] Rogers, E. M., 2003. Diffusion of Innovations. $5^{\text {th }}$ edition, New York.

[21] Wietschel, M., Dütschke, E., Funke, S. Peters, A., Plötz, P., Schneider, U., 2012. Kaufpotenzial für Elektrofahrzeuge bei sogenannten "Early Adoptern". Available online at http://isi.fraunhofer.de/isimedia/docs/e/de/publikationen/Schlussberich t_Early_Adopter.pdf, updated on $16 / 05 / 2012$, checked on 29/05/2012.
[22] Windisch, E., 2012. The impact of public policies on the adoption of privately owned electric vehicles - A socio-economic analysis. 11ème séminaire francophone est-ouest de socio-économie des transports. Karlsruhe.

[23] Windisch, E.; Leurent, F., 2012. L'acceptabilité potentielle des voitures électriques : Quelle profitabilité financière pour l'usager privé en Ile-de-France, in proceedings of Congres ATEC-ITS congress, Versailles.

[24] Eurostat Website, Energy price statistics, http://epp.eurostat.ec.europa.eu/statistics_ex plained/index.php/Energy_price_statistics, accessed on 2013-06-25.

\section{Authors}

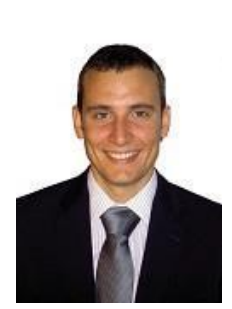

Axel Ensslen is reseach assistant at the French-German Iinstitute for Environmental Research and member of the research group "Transport and Energy" at the Chair of Energy Economics since 2011. He studied industrial engineering at the Karlsruhe Institute of Technology

(KIT), Germany and the Ecole Nationale Supérieure des Mines de Nancy (ENSMN), France. His research activities focus on socio-economic aspects of electric mobility.

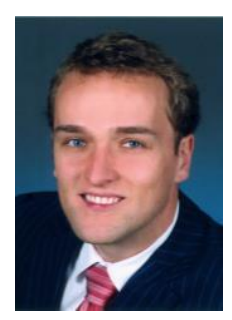

Patrick Jochem is since 2009 leader of the research group "transport and Energy" at the chair of energy economics at KIT. Since 2012 he is senior researcher at the Karlsruhe Service Research Institute. In 2009 he received his $\mathrm{PhD}$ in transport economics from Karlsruhe University. He studied economics at the universities in Bayreuth, Mannheim and Heidelberg, Germany. His research interests are in the fields of electric mobility and ecological economics.

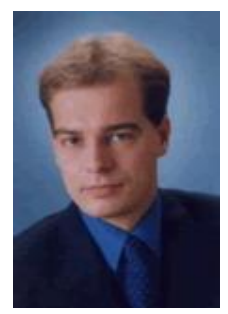

Wolf Fichtner is Director of the Institute for Industrial Production and the French -German Institute for Environmental Research. He is full professor and holder of the Chair of Energy Economics at KIT. His main areas of research are Energy System Modelling and the Techno-economic Analysis of Energy Technologies. 